\title{
TORAJYVÄN VILJELYKOKEISTA VIIKIN KOETILALLA JA ERÄILLÄ KASVINVILJELYSKOEASEMILLA SUOMESSA
}

\author{
Anna-LiIsa Ruokola \\ Helsingin yliopiston kasvipatologian laitos, Viikin koetila. \\ Saapunut 7. 6. 1956 .
}

Vilja- ja heinälajeissa loisivan torajyväsienen, Claviceps purpurea (Fr.) Tul.:n talvehtimisaste, torajyvä eli härkäjyvä, on myrkyllisyytensä takia aiheuttanut sekä ihmisten että eläinten lukuisia sairastumis- ja kuolemantapauksia $(2,27)$. Nykyisin myrkytystapaukset kuitenkin ovat verraten harvinaisia johtuen parantuneesta viljan viljelytekniikasta.

Torajyvää on toisaalta jo vuosisatojen ajan käytetty lääkeaineena, joskin se varsinaisena lääkkeenä otettiin käytäntöön vasta v. 1808 (11). Torajyvän sisältämiä alkaloideja, varsinkin sen jälkeen kun ne onnistuttiin eristämään puhtaina, on voitu menestyksellisesti käyttää sisäisiä verenvuotoja ehkäisemään sekä nykyään myös sisäeritys- ja hermotautien parannus- ja lievitysaineina.

Torajyväkantojen erilaisuudesta johtuen on luonnonvaraisen torajyvän alkaloidien sekä laatu että määrä eri maissa ja eri paikkakunnilla hyvin vaihteleva $(22,24)$. Skandinaavian maiden ja suomalaisen torajyvän alkaloidipitoisuus on yleensä erittäin pieni, kun se sitä vastoin espanjalaisessa ja portugalilaisessa torajyvässä on korkea $(1,4,10,11)$. Tästä on ollut seurauksena, että torajyvästä on tullut kansainvälinen kauppatavara, jonka myyntihinta on varsin korkea. Kun kuitenkin arvokkaan luonnonvaraisen torajyvän saanti on vuosi vuodelta vaikeutunut mm. tehokkaiden torjuntatoimenpiteiden vuoksi (1), on pyritty kehittämään rikasalkaloidisten torajyväkantojen viljelyä sekä keinoalustoilla että rukiin tähkissä. Edellisellä menettelytavalla tarkoitetaan sienen kuroma-asteen, Sphacelia segetum Lev.:in kasvattamista agari- ja muilla sopivilla kasvualustoilla. Tätä menetelmää kokeili ensimmäisenä BREFELD v. 1876 (vrt. 12). Hän siirrosti sienen koteloitiöitä eri kasvualustoille, mm. leivälle. Myöhemmin ovat lukuisat tutkijat $(8,9,12,13$, $14,18,23)$ suorittaneet vastaavanlaisia kokeita; tietyillä keinoalustoilla on siten 
opittu kehittämään sklerootioita $(12,23)$ ja alkaloidejakin $(9,14,18,23)$. Täten saaduilla alkaloideilla ei kuitenkaan ole ollut käytännöllistä merkitystä, joskin menetelmään liittyvien taloudellisten etujen vuoksi sitä edelleenkin pyritään kehittämään ainakin USA:ssa (30). Alkaloidien tuottaminen ei tällöin rajoittuisi kesäaikaan, jolloin maanviljelijöille muutenkin muodostuu työn huippuja. Toistaiseksi on kuitenkin rukiin tähkien saastuttaminen kuromilla ainoa keino kasvattaa sklerootioita, joiden alkaloidipitoisuus on käytännön vaatimuksia tyydyttävää. Koteloitiösaastutus ei ole osoittautunut yhtä sopivaksi, koska tällöin työn suorituksessa kohdataan käytännöllisiä vaikeuksia (1), jota paitsi koteloitiösaastutuksen seurauksena saadut sklerootiot eivät ole geneettisesti yhtä yhtenäisiä kuin ne, jotka syntyvät kuromista kasvaneista sienirihmoista $(4,25)$.

Käytäntöön perustuva torajyvän viljely on alun perin sveitsiläisen HEckEn $(7,8)$ ansiota, joskin vasta unkarilaisen von BÉkÉsyn (3) kehittämin menetelmin sienen viljelyä voitiin laajentaa verraten suurille peltoaloille. Lääketehdas Sandozin laajoilla torajyväviljelmillä Sveitsissä saadut ha-sadot ovat vaihdelleet 120 - $400 \mathrm{~kg}$, alkaloidipitoisuuden ollessa keskimäärin $0.43 \%$ (1).

Suomessa on torajyvän viljelyyn kiinnitetty huomiota vuodesta 1950 lähtien, jolloin Lääketehdas Leiras perusti ensimmäiset koeviljelmät Turkuun (1). Rukiin saastutus ja sadon korjuu on viime aikoina suoritettu koneellisesti. Tulokset ovat osoittaneet, että maamme pohjoisesta asemasta huolimatta täälläkin voidaan viljellä alkaloidipitoisuudeltaan arvokasta torajyvää. Samaa todistavat Helsingin yliopiston opetus- ja koetilalla Viikissä $\left(60^{\circ} 14^{\prime}\right.$ pohj. lev.) vuosina 1952 - 1955 sekä

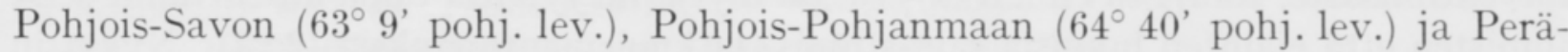
Pohjolan (66 $35^{\prime}$ pohj. lev.) kasvinviljelyskoeasemilla v. 1953 suoritettujen rukiin saastutuskokeiden tulokset, jotka seuraavassa joutuvat yksityiskohtaisen tarkastelun kohteeksi. Kokeet suoritettiin kasvipatologian laitoksella saksalaisen professori K. Mothesin pyynnöstä ja yhteistyönä hänen sekä suomalaisen lääket. tri P. A. JÄRVISEN kanssa.

\section{Koeolosuhteet, aineisto ja tutkimusmenetelmät}

Tutkimukset perustuvat osaksi laboratorio-, osaksi kenttäkokeisiin. Torajyvän eristäminen puhdasviljelmiksi samoin kuin saastutusmateriaalin lisäysviljely tapahtui huoneenlämpötilassa $\left(18-25^{\circ} \mathrm{C}\right)$. Valmiita viljelmiä säilytettiin jääkaapissa $\pm 0-8^{\circ} \mathrm{C}$ lämpötiloissa. Rukiin saastutuskokeet Viikissä sijoitettiin kasvipatologian laitoksen koekentälle sekä koetilan talousviljelmään, Maaningan, Ruukin ja Apukan kasvinviljelyskoeasemilla niinikään talousviljelmiin. Koemaa Viikissä oli hietaista liejusavea, liejusavea ja savihietaa.

Vuosina 1952 - 1955 torajyvän kasvuajan sää Helsingissä vaihteli huomattavasti (taulukko 1; 15). Niinpä v. 1955 kesäkuukaudet olivat poikkeuksellisen vähäsateisia ja kesäkuuta lukuunottamatta myös erittäin lämpimiä. Tuuli puhalsi vuosina 1952 - 1955 tavallisimmin etelästä tai lounaasta.

Saastutuskokeisiin käytetty kotimainen torajyväkanta eristettiin Viikin koetilalta Ensirukiin tähkistä v. 1950 poimituista sklerootioista. Kokeissa mukana olleet 
Taulukko 1. Sääsuhteet Helsingissä torajyvän kasvuaikana vuosina $1952-1955$.

Tabelle 1. Die Witterungsverhälnisse in Helsinki während der Vegetationsperiode des Mutterkornes in den Jahren $1952-1955$.

\begin{tabular}{|c|c|c|c|c|c|c|c|c|}
\hline \multirow{4}{*}{$\begin{array}{l}\text { Vuosi } \\
\text { Jahr }\end{array}$} & \multicolumn{8}{|c|}{ Poikkeamat normaalista - Abweichungen vom Normalen } \\
\hline & \multirow{2}{*}{\multicolumn{3}{|c|}{$\begin{array}{l}\text { Lämpötila }{ }^{\circ} \mathrm{C} \\
\text { Temperatur }{ }^{\circ} \mathrm{C}\end{array}$}} & \multirow[b]{3}{*}{ IX } & \multirow[b]{3}{*}{ VI } & \multirow{2}{*}{\multicolumn{3}{|c|}{$\begin{array}{c}\text { Sade } \mathrm{mm} \\
\text { Niederschlag } \mathrm{mm}\end{array}$}} \\
\hline & & & & & & & & \\
\hline & VI & VII & VIII & & & VII & VIII & IX \\
\hline 1952 & \pm 0.0 & -1.0 & -0.8 & -1.5 & \pm 0 & -14 & +13 & +38 \\
\hline 1953 & +3.2 & \pm 0.0 & +0.4 & -0.1 & +40 & +62 & -18 & +34 \\
\hline 1954 & -0.4 & +0.4 & +0.6 & +1.7 & -9 & +19 & +21 & +34 \\
\hline 1955 & -0.9 & +1.2 & +3.6 & +3.6 & -20 & 43 & -75 & -14 \\
\hline Norm. & 13.5 & 17.1 & 15.2 & 10.8 & 51 & 59 & 83 & 73 \\
\hline
\end{tabular}

ulkomaiset torajyväkannat olivat professori K. MoтHEsin Saksasta, Gaterslebenistä, lähettämät; ne saatiin laitokselle kuromaviljelminä. Torajyväkannoista käytetään tässä yhteydessä lyhennyksiä (vrt. 25):

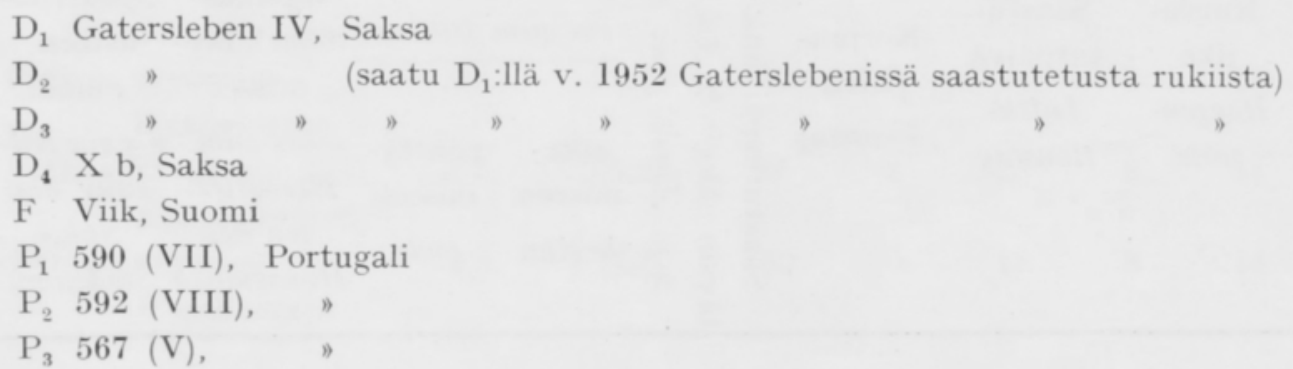

Torajyväkanta $\mathrm{D}_{3}$ :n kuromaviljelmien kasvattamiseen oli käytetty kappaleita viidestä eri sklerootiosta. $\mathrm{D}_{4}$ oli eristetty vehnästä, kaikki toiset rukiista.

Torajyvän viljelyyn sopivien ruislajikkeiden löytämiseksi otettiin saastutuskokeisiin mukaan kotimaiset syysruislajikkeet Ensi, Oiva ja Pekka sekä saksalaiset Petkus-syys- ja kevätrukiit (Viikissä). Maaningalla saastutettu ruis oli venäläinen Vjatka, Ruukissa ja Apukassa maatiaiskanta Greus. Rukiin ohella kokeiltiin ohran soveltuvuutta torajyvän kasvattamiseen.

Kuromien viljelyyn käytetyistä kasvualustoista (Kirchhoff-, Henneberg-, mallasuuteagari-, ruispuuro- ja vehnän-, ohran- ja maissinjyväseosalustat) osoittautui KIRchHoffin (12) suosittelema alusta sopivimmaksi, ilmeisesti sisältämänsä asparagiinin takia. Sitä paitsi agari-kasvualustalta kuromien irroittaminen oli helpompaa kuin jyväalustoilta. Sienen kuromien kasvattaminen aloitettiin siirrostamalla kasvualustalle sklerootion kappaleita, joista uloin kerros oli poistettu. Kuromien viljely suoritettiin keväällä, tavallisesti huhtikuun alusta alkaen.

Kuromasuspensio tähkien saastuttamista varten valmistettiin seuraavan ohjeen mukaisesti: 1 l. tislattua vettä, $10 \mathrm{~g}$ kidesokeria ja kuromaviljelmää keskimäärin $12 \mathrm{~cm}^{2}: \mathrm{n}$ alalta.

Saastutuksiin käytettiin n. 1 kuukauden ikäisiä viljelmiä. Saastutustyö suoritettiin osaksi prof. K. MoтHEsilta saadulla ja osaksi laitoksella valmistetulla siirros- 
tuslaudalla, johon kiinnitettyyn kumilevyyn oli upotettu ompelukoneen neuloja (vrt. 28, 29, 31). Saastutusvälineisiin kuului lisäksi kumilevy tähkien kokoamista varten. Työ tapahtui siten, että siirrostuslaudan neulaosa upotettiin kuromasuspensioon ja neuloihin tarttunut neste sirrrettiin välittömästi rukiin tähkiin painamalla laite kumilevyyn siten, että tähkät jäivät sen ja siirrostuslaudan väliin. Saastutustyössä ei korsien vioittumista voitu kokonaan välttää, mikä siten jossakin määrin alensi jyvä- ja torajyväsatoja.

Ruis saastutettiin $0-13$ päivää (taulukot 2 ja 3 ) ja ohra $0-1$ päivää ennen kuin ne alkoivat kukkia, eli silloin kun rukiin tähkistä oli $1-100 \%$ ja ohran täh-

Taulukko 2. Havaintoja rukiin torajyväsaastunnan vaiheista Viikissä vuosina 1952 - 1955 suoritetuissa kokeissa.

Tabelle 2. Beobachtungen über die Stadien der Mutterkorninfektion bei Roggen in den auf Viik in den J. 1952-1955 ausgeführten Versuchen.

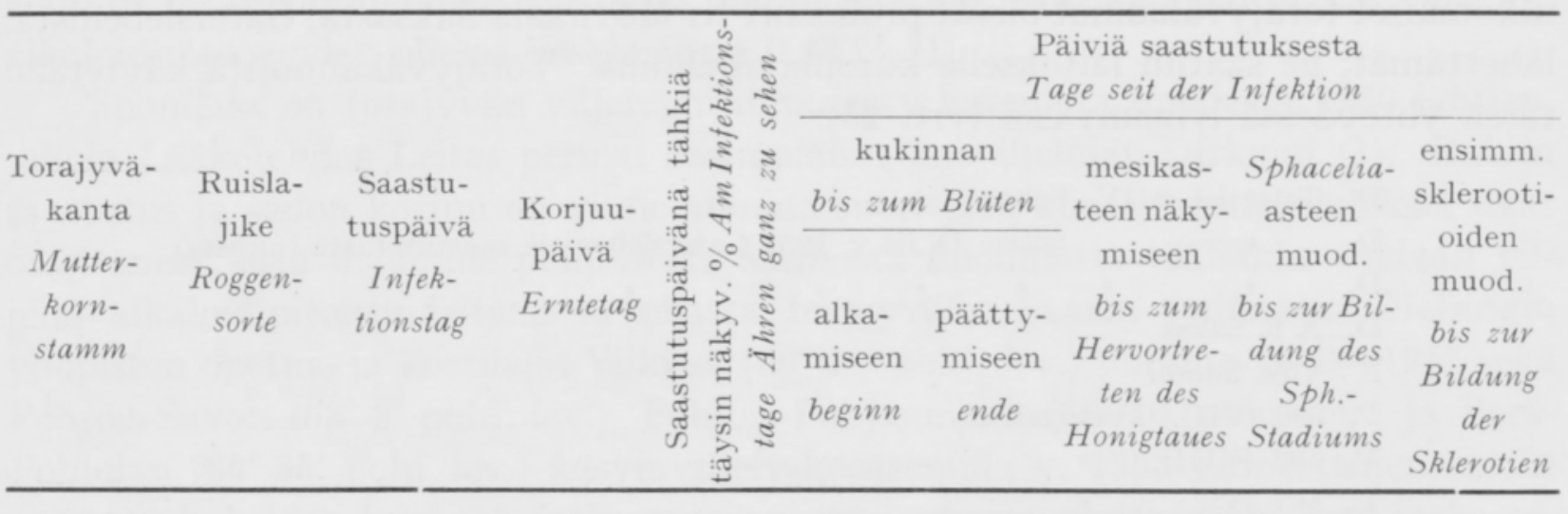

1952

$\begin{array}{lccrrrrrrr}\mathrm{F} & \text { Ensi } & 20 .-21.6 . & 9.8 & 75 & 6.5 & 13.5 & 8.0 & 11.0 & 13.0 \\ \mathrm{D}_{1} & \text { " } & 20.6 . & 12.8 & 70 & 7.0 & 14.0 & 9.0 & 12.0 & 20.0 \\ \text { " } & \text { Oiva } & 16.6 . & 7.8 . & 50 & 5.0 & 18.0 & 8.0 & 12.0 & 20.0 \\ \text { " } & \text { Pekka } & 13.6 . & 11.8 & 45 & 7.0 & 21.0 & 8.0 & 12.0 & 19.0\end{array}$

1953

$\begin{array}{lcrrrrrrrr}\mathrm{F} & \text { Ensi } & 13.6 & 3.8 . & 14 & 8.0 & 17.0 & 6.0 & 10.0 & 13.0 \\ \mathrm{D}_{1} & " & 12.6 & 1.8 . & 90 & 7.0 & 18.0 & 7.0 & 13.0 & 16.0 \\ \mathrm{D}_{4} & " 1 & 12.6 . & 31.7 & 60 & 7.0 & 18.0 & 7.0 & 13.0 & 16.0\end{array}$

1954

$\begin{array}{lrrrrrrrrr}\mathrm{F} & \text { Ensi } & 9.6 . & 31.7 . & 27 & 13.0 & 21.0 & 10.7 & 14.0 & 17.0 \\ \mathrm{D}_{1} & \text { ") } & 9.6 . & 3.8 & 9 & 13.0 & 21.0 & 10.3 & 14.3 & 23.0 \\ \mathrm{D}_{2} & \text { ") } & 9.6 . & 3.8 . & 27 & 13.0 & 21.0 & 10.7 & 17.7 & 21.0 \\ \mathrm{P}_{2} & \text { " } & 9.6 . & 3.8 . & 43 & 13.0 & 21.0 & 9.0 & 16.6 & 20.3 \\ \mathrm{P}_{3} & \text { " } & 9.6 . & 31.7 . & 27 & 13.0 & 21.0 & 10.0 & 15.3 & 24.3\end{array}$

1955

$\begin{array}{lcrccccccc}\mathrm{F} & \text { Ensi } & 27.6 . & 12.8 . & 90 & 5.7 & 12.3 & 9.0 & 13.0 & 17.3 \\ \mathrm{D}_{1} & \text { ") } & 27.6 . & 12 .-13.8 & 90 & 7.3 & 13.3 & 9.0 & 14.0 & 18.3 \\ \mathrm{P}_{2} & \text { " } & 27.6 . & 13.8 . & 67 & 7.7 & 14.0 & 9.0 & 14.7 & 18.7 \\ \mathrm{P}_{3} & \text { " } & 27.6 . & 15.8 . & 93 & 7.0 & 12.7 & 10.3 & 15.0 & 19.3\end{array}$


Taulukko 3. Havainnot torajyväsaastunnan vaiheista Petkus-kevät- ja syysrukiissa v. 1952. Tabelle 3. Beobachtungen über die Stadien der Mutterkorninfektion bei dem Sommer-und dem Winterroggen Petkus im J. 1952.

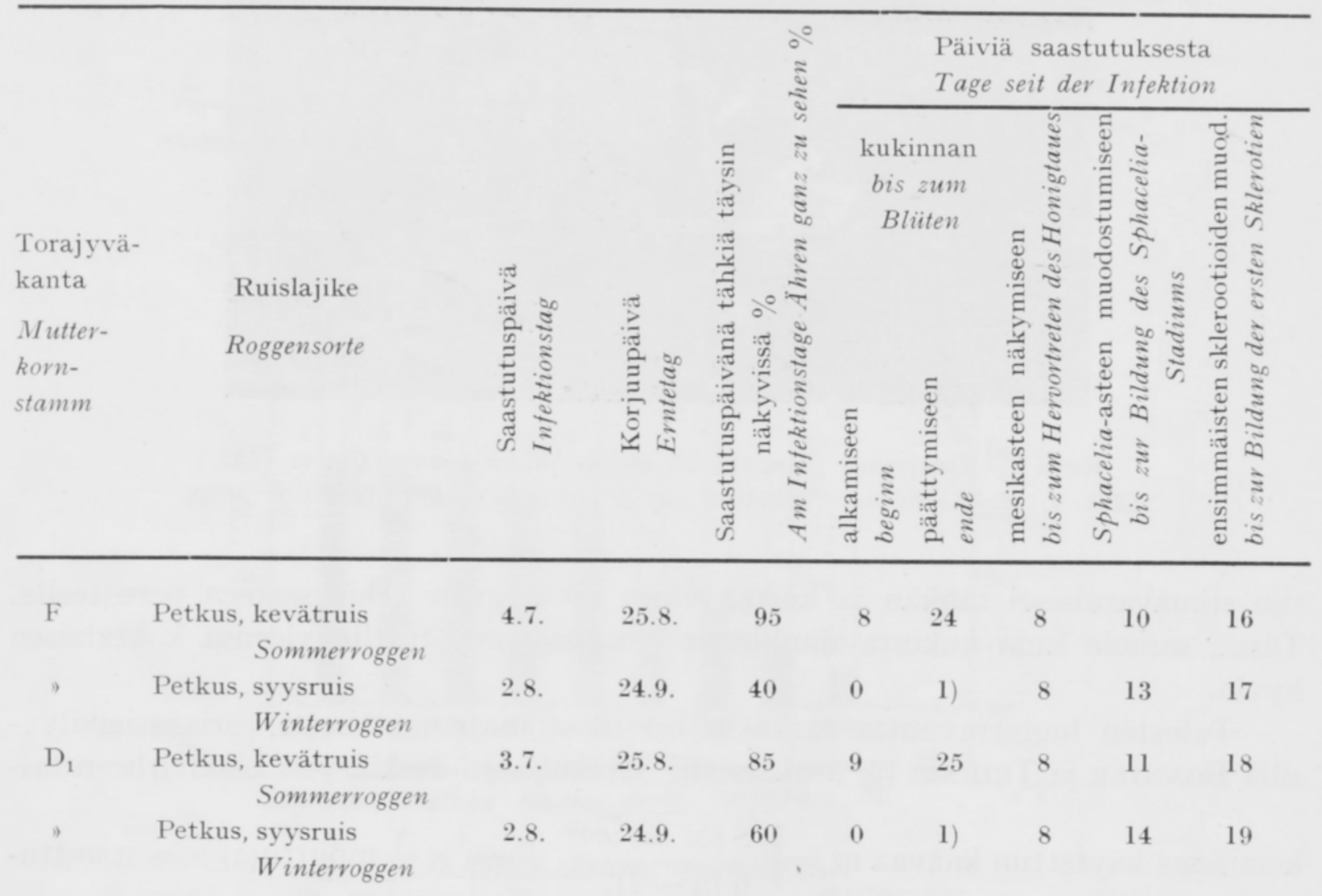

kistä 10-60\% vapautunut lehtitupesta. Ensirukiissa suoritettiin v. 1952 saastutusaikakoe, jossa eri koeruutujen kasvustot saastutettiin 1-2 päivän väliajoin (kuva 2). Koeruutujen luku ja koko on selostettu tulosten yhteydessä.

Petkus-syysruis kylvettiin v. 1952 välittömästi 24.4.-27.5. tapahtuneen jarovisoinnin jälkeen. Jarovisointia varten jyviä liotettiin vedessä $4 \mathrm{t}$. Tämän jälkeen niitä säilytettiin kosteina aluksi jääkaapissa (lämpötila $\pm 0-8^{\circ} \mathrm{C}$ ) 2 viikon ajan ja lopun ajasta eli 20 päivää termostaattihuoneessa (lämpötila $1-1.5^{\circ} \mathrm{C}$ ).

Torajyvien korjuutyössä käytettiin kahta eri menetelmää. Muutamien koeruutujen sadot niitettiin viikatteella, koottiin lyhteiksi ja vietiin varisemista varoen latoon, jossa sklerootiot poimittiin tähkistä ja niiden luku laskettiin. Torajyvät tuotiin paperipusseissa laboratorioon, jossa ne punnittiin sen jälkeen kun ne olivat kuivahtaneet. Suurin osa sklerootioista poimittiin kuitenkin niiden kasvupaikalla, koska tällöin variseminen korjuutyön aikana voitiin melkein kokonaan välttää. Tähkissä säilyneiden sekä maahan varisseiden torajyvien laskeminen suoritettiin yleensä vain saastutetun koeruudun osalta $\left(0.5-3 \mathrm{~m}^{2}\right.$; kuva 1$)$.

Pääosa torajyvistä otettiin talteen $\mathrm{n}$. viikkoa ennen rukiin tuleentumista, loput vasta sen tuleentumisaikana (taulukot 2 ja 3). Rukiin tuleentumisaika arvioi-

1) Kukinta jatkui talveen asti.

Die Blüte dauerte bis zum Winter. 


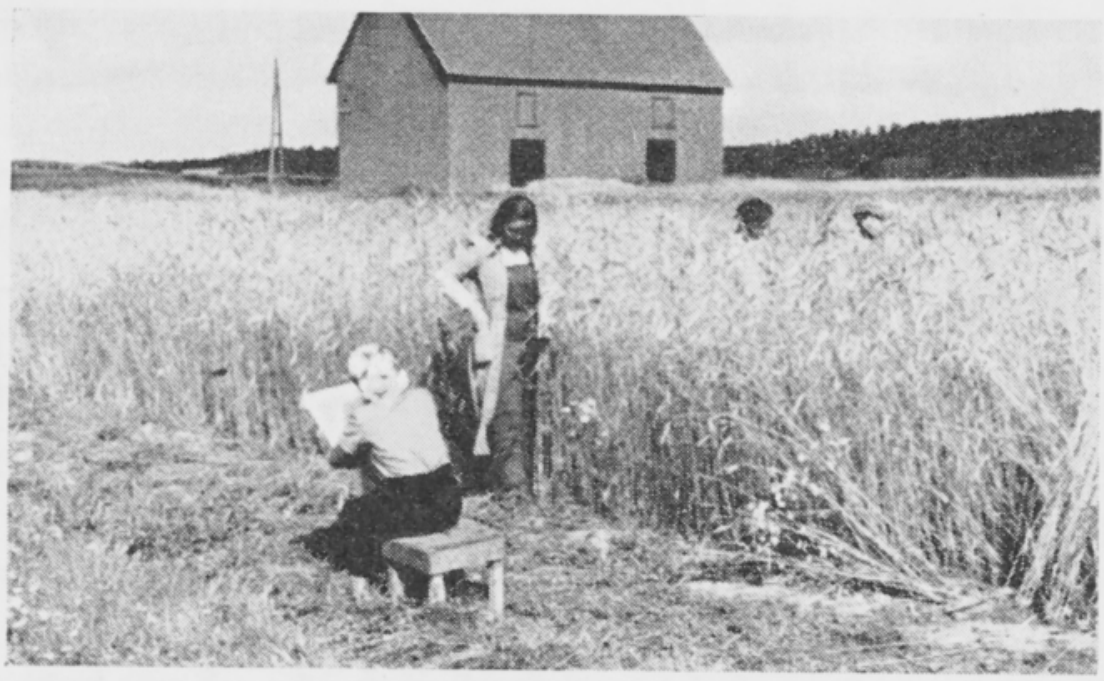

Kuva 1. Torajyvien poiminta käynnissä Viikin koekentällä v. 1952. $A b b$. 1. Bei Lesen von Mutterkorn auf dem Versuchsfeld Viik im J. 1952.

tiin silmävaraisesti tähkän ja korren värin sekä jyvän kehitysasteen perusteella. Tässä, samoin kuin kukinta-ajankin arvioinnissa onnistuttiin yleensä kohtalaisen hyvin.

Tulosten luotettavuutta tarkasteltiin tilastomatemaattisesti varianssianalyysillä Bonnier ja Tedinin (5) mukaisesti. Koetulosten keskiarvon keskivirheen laskemisessa käytettiin kaavaa $m=\sqrt{\frac{S(x-\bar{x})^{2}}{n(n-1)}}$ jossa $x=$ muuttuja, $\bar{x}=$ muuttujien keskiarvo ja $n=$ muuttujien lukumäärä. Keskiarvojen erotuksen keskivirhe laskettiin kaavasta $\sqrt{\mathrm{m}_{1}{ }^{2}+\mathrm{m}_{2}{ }^{2}}$.

\section{Torajyväsaastunnan kulku}

V. 1952 suoritetusta erikoiskokeesta (kuva 2) ilmeni, että torajyväsaastunta oli voimakkain, kun tähkien kuromakäsittely suoritettiin 6 -8 päivää ennen rukiin kukintaa eli silloin, kun 35-85\% rukiin tähkistä oli vapautunut lehtitupesta. Myös muissa kokeissa suoritettiin torajyväsaastutus rukiin ollessa jonkin verran eri kehitysasteilla (taulukko 2). Saastutuksen ajankohdalla, kun se tapahtui 9.6.27. 6. ei näyttänyt olevan selvää vaikutusta torajyväsienen kehityksen kulkuun, sen Sphacelia-asteen eikä sklerootioiden muodostumisen alkamiseen.

Mesikaste ilmaantui 6-11 päivää saastutuksen jälkeen, useimmiten lähes samanaikaisesti rukiin kukinnan alkamisen kanssa. Ensimmäiset sklerootiot näyttäytyivät jo muutamia päiviä yleisen kukinnan alkamisen jälkeen, useissa tapauksissa kuitenkin vasta sen päätyttyä. Kotimaisen torajyväkannan sklerootioiden kehitys osoittautui keskimäärin vähän nopeammaksi kuin muiden. Myös eri koevuosina torajyvien kehityksen nopeudessa ilmeni eroja; nämä ilmeisesti johtuivat erilaisista sääsuhteista saastunnan alkuvaiheessa. 

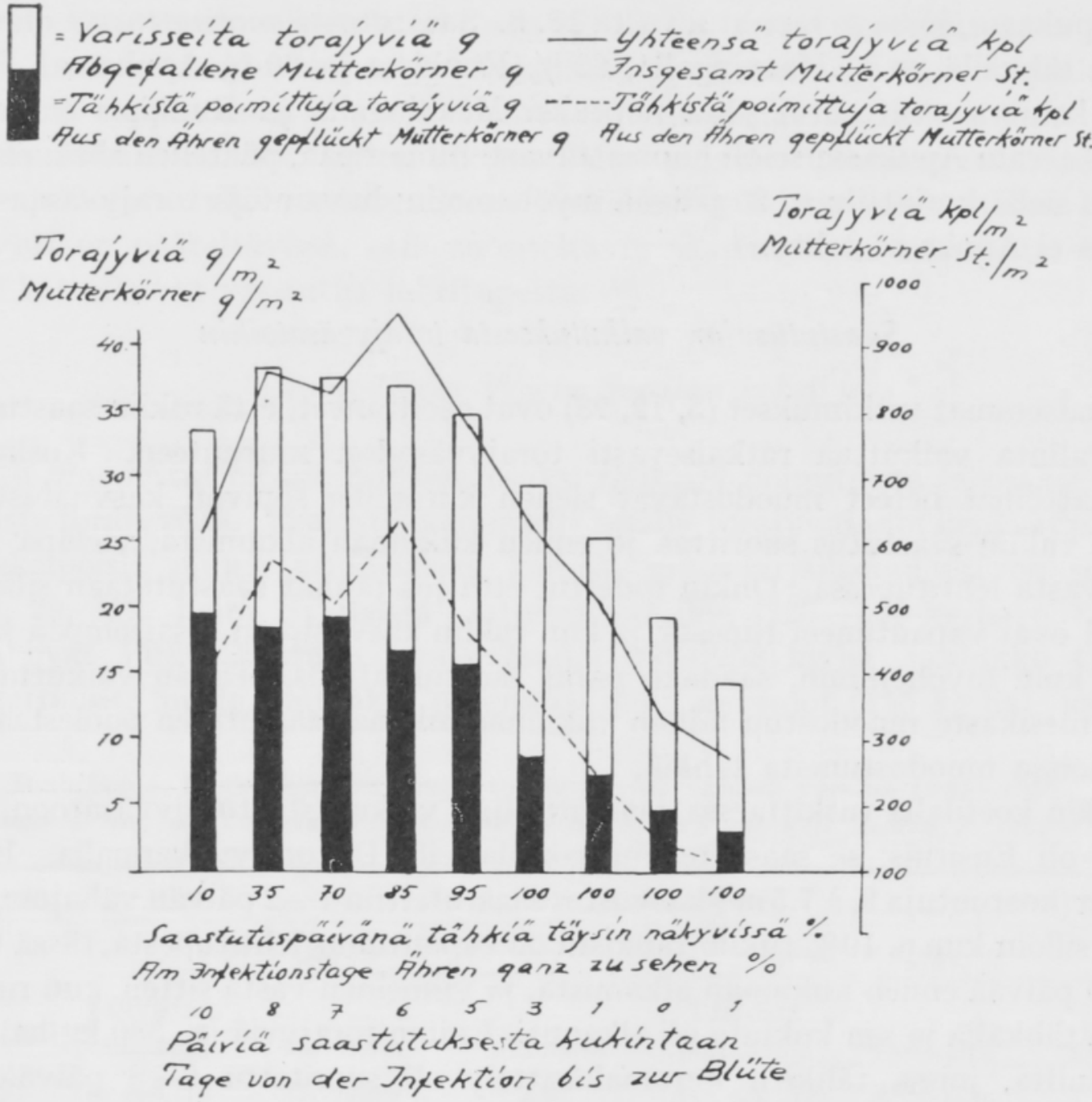

Kuva 2. Saastutusajan vaikutus $\mathrm{D}_{1}: 11$ ä saastutetun Ensirukiin torajyväsatoon v. 1952. (Viideltä ensiksi saastutetulta koeruudulta torajyvät korjattu 12. 8., loput alkaloidipitoisuustutkimuksia varten 21. 8.). Abb. 2. Der Einfluss der Infektionszeit auf den Mutterkornertrag des mit $D_{1}$ infizierten Roggens Ensi im J. 1952. (Von den fünf zuerst infizierten Parzellen die Mutterkörner am 12. 8. geerntet, die übrigen für Alkaloidgehaltuntersuchungen am 21. 8.)

Huolimatta siitä, että Petkus-kevätrukiissa torajyvän kasvuaika sattuu syyspuolelle kasvukautta, ei sienen kehityksen kulussa havaittu mitään normaalista poikkeavaa (taulukko 3).

Jotta päästäisiin varmuuteen siitä, missä määrin torajyvän alkaloidipitoisuus on riippuvainen ruislajikkeesta, otettiin kokeiltavaksi myös saksalainen syysruislajike, Petkus, jonka siemen saapui kuitenkin niin myöhään, että se kesän 1952 kokeita varten oli jarovisoitava. Jarovisaation vaikutus osoittautui sikäli puutteelliseksi, että melkoinen osa kasvustosta ei saastutusaikana, 2. päivänä elokuuta, ollut vielä ehtinyt orasastetta pitemmälle. Torajyväsaastunnan ja Sphacelia-asteensamoin kuin sklerootioiden muodostumisen väliseen aikaan ei jarovisaatiolla kuitenkaan ollut näkyvää vaikutusta.

V. 1953 Maaningan, Ruukin ja Apukan kasvinviljelyskoeasemilla rukiin (Vjatka, Greus) saastutus suoritettiin 15.-18.6. sekä torajyvien korjuu 28.-29.7. muualla 
paitsi Apukassa, jossa se tapahtui vasta 18. 8. Saastutusta suoritettaessa oli rukiista täydellä tähkällä $90 \%$ Maaningalla, $62 \%$ Ruukissa ja $30 \%$ Apukassa. Sklerootioiden kehitys osoittautui yhtä nopeaksi Maaningalla ja Ruukissa kuin EteläSuomessa, vain Apukassa se oli huomattavasti hitaampaa, päätellen siitä, että torajyväsato siellä korjattiin n. 20 päivää myöhemmin; havaintoja torajyväsaastunnan vaiheista ei Apukassa tehty.

\section{Saastutusajan vaikutuksesta torajyväsatoihin}

Aikaisemmat tutkimukset $(3,12,28)$ ovat osoittaneet, että rukiin saastutusajan oikea valinta vaikuttaa ratkaisevasti torajyväsadon suuruuteen. Koska myös kypsymättömät heteet muodostavat sienen kuromille sopivan kasvualustan (3), voidaan rukiin saastutus suorittaa jo ennen kukinnan alkamista, vieläpä tähkien ollessa vasta lehtitupessa. Onkin todettu, että jos tähkät saastutetaan silloin kun ne juuri ovat vapautuneet tupesta, ja kun rukiin kasvusto on tasaisempaa ja matalampaa kuin myöhemmin, saadaan paras saastuntatulos. Tähän vaikuttaa myös se, että mesikaste muodostuu tällöin kukinnan aikana saastuttaen puolestaan myöhäisversoissa muodostuneita tähkiä.

Viikin koetilalla tutkittaessa saastutusajan vaikutusta torajyväsatoon, isäntäkasvina oli Ensiruis; se saastutettiin saksalaisella $\mathrm{D}_{1}$-torajyväkannalla. Eri koeruutujen (koeruutuja 9 , à $7.5 \mathrm{~m}^{2}$ ) kasvustot saastutettiin $1-2$ päivän väliajoin, ensimmäinen silloin kun n. $10 \%$ rukiin tähkistä oli vapautunut lehtitupesta, tässä tapauksessa 10 päivää ennen kukinnan alkamista, ja viimeinen vasta sitten, kun ruis oli jo täydellä tähkällä ja sen kukinta oli alkanut. Eniten torajyviä (n. $380 \mathrm{~kg} / \mathrm{ha}$ ) saatiin koeruuduilta, joissa tähkien kuromakäsittely oli suoritettu 6 - 8 päivää ennen kukintaa eli silloin, kun 35-85\% tähkistä oli täysin näkyvissä (kuva 2). Sen sijaan koeruutujen sato, joissa rukiin saastutus oli suoritettu vasta $1-3$ päivää ennen kukintaa tai sen jo alettua, jäi suhteellisen pieneksi. Viimeiseksi saastutetun ruudun torajyväsato oli vain $141 \mathrm{~kg} / \mathrm{ha}$.

Eri saastutuspäivien keskilämpötilat vaihtelivat $11.8-17.9^{\circ} \mathrm{C}$; ensimmäisten saastutuspäivien lämpötila oli kuitenkin keskimäärin lähes sama kuin viimeisten. Sateita sattui 1., 3. ja 6. saastutuspäivänä, mutta lienee niiden samoin kuin lämpötilankin erikoisvaikutus eri koeruutujen satoihin jäänyt varsin vähäiseksi. Mesikasteen ilmaantuessa eri koeruutujen tähkiin (25.6. - 4.7.) vallitsi pitkäaikainen poutakausi.

Toisessa koesarjassa, jossa Oiva- ja Pekkarukiiden torajyväsadot muodostuivat varsin suuriksi, saastutus suoritettiin ajankohtina, joina tähkistä oli näkyvissä $10-85 \%$.

Oiva

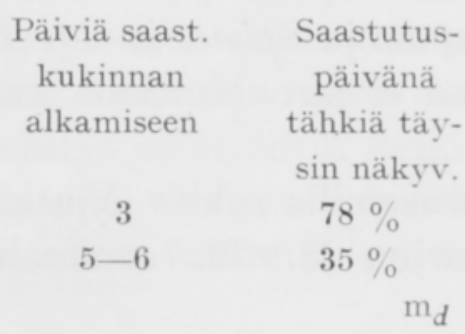

Pekka

$\begin{array}{cc}\begin{array}{c}\text { Torajyvä- } \\ \text { sato } \\ \mathrm{kg} / \mathrm{ha}\end{array} & \begin{array}{c}\text { Päiviä saast. } \\ \text { kukinnan } \\ \text { alkamiseen }\end{array} \\ 357.5 \pm 33.5 & 6-7 \\ 359.5 \pm 41.6 & 8 \\ 2.0 \pm 53.4 & \end{array}$

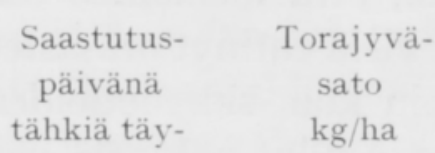

sin näkyv.

$50 \%$

$10 \%$
$539.4+40.1$ $506.3+70.5$ $33.1 \pm 81.1$ 
Keski-Euroopassa suositellaan usein $(3,12,28)$ torajyväsaastutuksen suorittamista n. 1-2 viikkoa ennen rukiin kukintaa. Kun rukiin kukinnan ajankohta on sääsuhteista riippuvainen ja säätä ei osata tarkasti ennustaa, tuntuu kuitenkin tarkoituksenmukaisemmalta, kuten ulkomaillakin monesti tehdään, määrätä saastutuksen ajankohta rukiin kehitysasteen mukaisesti. Edellä selostettujen kokeiden mukaisesti on pääteltävissä, että suositeltavin saastutuksen ajankohta on silloin kun tähkät alkavat vapautua lehtitupesta.

\section{Torajyväsadot Viikin koetilan kokeissa}

Sato muodostui näissä kokeissa osaksi tähkistä poimituista ja osaksi maahan varisseista torajyvistä. Tähkistä poimimalla saadut torajyväsadot lienevät parhaiten vertailukelpoisia niiden satomäärien kanssa, joita kirjallisuudessa on selostettu $(1,3,8,29,31)$. Esim. Sveitsissä saatuihin satoihin $(120-400 \mathrm{~kg} / \mathrm{ha}$; vrt. 1) verrattuna ovat Viikin koetilan torajyväsadot (83-258 kg/ha; taulukko 4) tuskin keskinkertaiset, mutta kuitenkin paremmat kuin ne sadot (115 kg/ha), joita Suo-

Taulukko 4. Keskimääräiset rukiin torajyväsadot Viikissä vuosina 1952-1955.

Tabelle 4. Durchschnittliche Mutterkornerträge bei Roggen auf Viik in den J. 1952-195.5.

\begin{tabular}{|c|c|c|c|c|c|c|}
\hline \multirow{3}{*}{$\begin{array}{l}\text { Vuosi } \\
\text { Jahr }\end{array}$} & \multicolumn{6}{|c|}{ Torajyviä - Mutterkörner } \\
\hline & & $\mathrm{kg} / \mathrm{ha}$ & & $\mathrm{kpl} / \mathrm{m}^{2}$ & $-S t . / m^{2}$ & \\
\hline & $\begin{array}{l}\text { Tähkistä } \\
\text { poimittuja } \\
\text { Aus den Äh- } \\
\text { ren gepflückt }\end{array}$ & $\begin{array}{l}\text { Varisseita } \\
\text { Abgefallen }\end{array}$ & $\begin{array}{c}\text { Yhteensä } \\
\text { Zus. }\end{array}$ & $\begin{array}{l}\text { Tähkistä } \\
\text { poimittuja } \\
\text { Aus den Äh- } \\
\text { ren gepflückt }\end{array}$ & $\begin{array}{l}\text { Varisseita } \\
\text { Abgefallen }\end{array}$ & $\begin{array}{c}\text { Yhteensä } \\
\text { Zus. }\end{array}$ \\
\hline 1952 & 257.7 & 249.9 & 507.6 & 805 & 444 & 1249 \\
\hline 1953 & 154.6 & 109.4 & 264.0 & 480 & 202 & 682 \\
\hline 1954 & 82.6 & 151.8 & 234.4 & 299 & 492 & 791 \\
\hline 1955 & 165.4 & 19.0 & 184.4 & 324 & 16 & 340 \\
\hline
\end{tabular}

messa Lääketehdas Leiraksen johtajan, proviisori E. AHon ystävällisen ilmoituksen mukaan on käytännön torajyväviljelmillä saatu. Sadon määrän vaihtelu eri vuosina Viikin koetilan kokeissa oli hyvin tuntuva; v. 1952, jolloin saastutusajan sää oli kostea, sadon määrä muodostui suurimmaksi. Sen sijaan v. 1954 torajyviä varisi suhteellisesti eniten, joten poimittu sato jäi varsin pieneksi. Tällainenkin sato ( $83 \mathrm{~kg} / \mathrm{ha})$ kannattaa silti ilmeisesti ottaa talteen, varsinkin kun ruissato muodostuu silloin vastaavasti suhteellisen suureksi ja pääosa siitä voitaneen käyttää ihmisen ravinnoksi tai kotieläinten rehuksi. Tosin Viikissä suoritetut tutkimukset, joiden yksityiskohtaiset tulokset esitetään myöhemmin toisessa yhteydessä, viittaavat siihen, että ellei lajittelumenetelmä ole kyllin tehokas, torajyviä pyrkii ruissatoon jäämään tavallista enemmän.

Vaikka lähes kaikki torajyväsadot korjattiin sklerootioiden pääosan kypsymisaikaan eli n. viikkoa ennen rukiin tuleentumista (osalta Pekka- ja Ensirukiin 




Kuva 3. Korjuuajan vaikutus $D_{1}-$ ja $F$ - torajyväkannoilla saastutetun Ensirukiin torajyväsatoihin v. 1952 .

$A b b$. 3. Der Einfluss der Erntezeit auf die Mutterkornerträge des mit den Mutterkonrnstämmen $D_{1}$ und $F$ infizierten Roggens Ensi im J. 1952

saastutettuja koeruutuja v. 1952 torajyväsato korjattiin vasta rukiin tuleentumisaikana; kuva 3), oli keskimääräinen varisemistappio vuosina 1952 - 1955 varsin suuri, $41.4 \%$, äärimmäistapauksessa lähes $80 \%$. Mielenkiintoista on, että kuivimpana vuonna 1955 varisemistappio oli selvästi kaikkein pienin $(10.3 \%$ ); torajyvät olivat silloin todettavasti tiukemmin kiinni tähkissä kuin muina vuosina. Koko torajyväsato (poimitut + varisseet) jäi v. 1955 kuitenkin suhteellisen pieneksi. Käytännön viljelyssä torajyvän variseminen muodostuu tärkeäksi probleemaksi, koska varisseiden torajyvien poimiminen maasta ei ole kannattavaa (1). Varisemistappion suuruuden pääsyynä lienee se, että rukiin saastuminen ei tapahdu kauttaaltaan samanaikaisesti, vaan osa tähkistä saa tartunnan jo saastutuksen yhteydessä, osa vasta ensiksi saastuneissa tähkissä muodostuneesta mesikasteesta. Kun saastumista siten tapahtuu pitkähkön ajan kuluessa, rukiin sivuversojen ilmaantumisen mukaisesti, ja myöhemmin muodostuvien sklerootioiden tuleentuessa vanhimmat sklerootiot jo varisevat, varisemistappio on parannetuinkaan saastutusmenetelmin 
tuskin vältettävissä. Jos taas sklerootiot korjataan tuleentumattomina, jää niiden alkaloidipitoisuus suhteellisen pieneksi (17, 22, 25); ensimmäisten sklerootioiden alkaloidipitoisuus on kaikkein suurin $(1,4,25)$. Tutkimustyössä lienee syytä kiinnittää erityistä huomiota parhaan korjuuajan löytämiseen niin sadon varisemistappiota ja alkaloidipitoisuutta kuin sen koneellista korjuutakin silmällä pitäen.

\section{Torajyväsadot kasvinviljelyskoeasemilla}

Torajyvien alkaloidipitoisuuteen mahdollisesti vaikuttavien ilmastollisten tekijäin osuuden selvittämiseksi suoritettiiin v. 1953 rukiin saastutuksia paitsi Viikissä, myös kolmella pohjoisella kasvinviljelyskoeasemalla, Apukassa, Ruukissa ja Maaningalla. Rukiin saastuttamiseen Ruukissa ja Apukassa valittiin eniten alkaloideja sisältävät, portugalilaiset torajyväkannat $\left(\mathrm{P}_{1}, \mathrm{P}_{2}\right.$ ja $\left.\mathrm{P}_{3}\right)$; Maaningalla saastutuksiin käytettiin $\mathrm{D}_{2}$ - ja $\mathrm{D}_{3}$ - torajyväkantoja, jotka välittömästi polveutuvat saksalaisesta $\mathrm{D}_{1}$-torajyväkannasta (vrt. s. 205). Ruukissa korjattu keskimääräinen torajyväsato (160 kg/ha; taulukko 5) oli Viikin koetilan kokeissa saatua vastaavaa satoa (155

Taulukko 5. Torajyväsadot eri kasvinviljelyskoeasemilla v. 1953. Koealat $25 \mathrm{~m}^{2}$, ilman kerrannaisia. Tabelle 5. Mutterkornerträge an den verschiedenen Versuchsstationen für Pflanzenbau im J. 1953. Probeflächen $25 \mathrm{~m}^{2}$, ohne Wiederholungen.

\begin{tabular}{|c|c|c|c|c|c|}
\hline \multirow[b]{2}{*}{$\begin{array}{l}\text { Koeasema } \\
\text { Versuchs- } \\
\text { station }\end{array}$} & \multirow{2}{*}{$\begin{array}{l}\text { Torajyvä- } \\
\text { kanta } \\
\text { Mutterkorn- } \\
\text { stamm }\end{array}$} & \multirow[b]{2}{*}{$\begin{array}{l}\text { Ruislajike } \\
\text { Roggensorte }\end{array}$} & \multicolumn{3}{|c|}{$\begin{array}{l}\text { 1) Torajyviä (tähkistä poimittuja) } \\
\text { Mutterkörner (aus den Ähren gepflïckt) }\end{array}$} \\
\hline & & & $\mathrm{kg} / \mathrm{ha}$ & $\begin{array}{l}\mathrm{kpl} / \mathrm{m}^{2} \\
\mathrm{St} . / \mathrm{m}^{2}\end{array}$ & $\begin{array}{l}\text { keskim. } \\
\text { kpl/tähkä } \\
\text { im Mittel } \\
\text { St./Ahre }\end{array}$ \\
\hline Maaninka & $\mathrm{D}_{2}$ & Vjatka & $20.7 \pm 3.6$ & $84 \pm 12$ & $0.2 \pm 0.03$ \\
\hline " & $\mathrm{D}_{3}$ & $B$ & $144.7 \pm 36.7$ & $385 \pm 99$ & $1.3 \pm 0.32$ \\
\hline Ruukki & $P_{1}$ & Greus & $190.2 \pm 43.2$ & $703 \pm 174$ & $1.8 \pm 0.28$ \\
\hline " & $\mathrm{P}_{2}$ & $"$ & $129.0 \pm 9.6$ & $494 \pm 35$ & $1.3 \pm 0.10$ \\
\hline Apukka & $\mathrm{P}_{3}$ & $"$ & $80.2 \pm 15.0$ & $275 \pm 86$ & $0.9 \pm 0.18$ \\
\hline
\end{tabular}

$\mathrm{kg} / \mathrm{ha}$; taulukko 4) jopa vähän parempi; Maaningalla ja Apukassa saatu torajyvien määrä sen sijaan jäi suhteellisen vähäiseksi $(80-83 \mathrm{~kg} / \mathrm{ha})$. Torajyväkanta $\mathrm{D}_{2}: \mathrm{n}$ huonoon satotulokseen Maaningalla eivät paikalliset erikoisolosuhteet liene olleet syynä, koska tämän torajyväkannan sato myös Viikissä jäi varsin heikoksi (taulukko 6). Apukassa saatua torajyväsatoa ilmeisesti alensi se, että ruis oli täällä heikosta talvehtimisesta johtuen suhteellisen harvaa. Torajyvät ennättivät kuitenkin täälläkin täysin kehittyä, mikä oli myös odotettavaa, koska torajyvät yleensäkin tuleentuvat ennen rukiin jyväsadon kypsymistä. Torajyvän kasvuajan, kesä-elokuun, lämpötila oli Apukassa keskimäärin $2^{\circ} \mathrm{C}$ alhaisempi kuin Helsingissä (vrt. taulukko 1). Kuitenkin kesäkuun keskilämpötila oli Apukassa suhteellisen korkea, $17.1^{\circ} \mathrm{C}$. Kaikki kesäkuukaudet olivat siellä runsassateisia.

$\left.{ }^{1}\right)$ Varisemishavainnot puuttuivat.

Beobachtungen über das Abfallen fehlten. 


\section{Torajyväkantojen vertailu}

Vuosina 1953-1955 suoritettiin eri torajyväkannoilla rukiin saastutuksia, joissa kotimainen kanta, F, oli mukana kaikkina kolmena koevuonna, saksalainen $\mathrm{D}_{1}$ ja portugalilaiset torajyväkannat, $\mathrm{P}_{2}$ ja $\mathrm{P}_{3}$, vuosina 1954 ja 1955 sekä $\mathrm{D}_{1}$ kannasta polveutuva $\mathrm{D}_{2}$ vuosina 1953 ja 1954. Torajyväkannat viljeltiin Ensirukiissa. Kokeissa todettiin luotettavia satoisuuseroja eri torajyväkantojen välillä (taulukot 6 ja 7 ). Ulkomaisista torajyväkannoista $D_{1}$ ja $P_{2}$ osoittautuivat viljelyvarmemmiksi ja satoisammiksi kuin $\mathrm{P}_{3}$; varsinkin v. 1955 viimeksi mainitun torajyväkannan sato jäi erittäin pieneksi $(22 \mathrm{~kg} / \mathrm{ha}) . \mathrm{D}_{1}: \mathrm{n}$ satotulokset (tähkistä poimitut + maahan varisseet) olivat $211-295 \mathrm{~kg} / \mathrm{ha}$ ja $\mathrm{P}_{2}: \mathrm{n} 208-225 \mathrm{~kg} / \mathrm{ha}$.

$\mathrm{D}_{2}$-torajyväkannalla saastutetuissa tähkissä v. 1953 sklerootioiden kasvu useissa tapauksissa pysähtyi jo Sphacelia-asteeseen (taulukko 6). Mistä tämä johtui, ei ole varmuudella pääteltävissä. Saprofyyttisiä sieniä, jotka kirjallisuuden mukaisesti toisinaan tukahduttavat torajyväsienen kasvun $(16,19)$, tähkissä ei havaittu eikä

Taulukko 6. F- ja $\mathrm{D}_{2}$-torajyväkantojen sadot v. $1953\left(3 \times 2 \mathrm{~m}^{2}\right)$.

Tabelle 6. Die Evträge der Mutterkornstämme $F$ und $D_{2}$ im J. $1953\left(3 \times 2 \mathrm{~m}^{2}\right)$.

\begin{tabular}{|c|c|c|c|c|c|c|}
\hline \multirow[b]{2}{*}{$\begin{array}{c}\text { Torajyvä- } \\
\text { kanta } \\
\text { Mutterkorn- } \\
\text { stamm }\end{array}$} & \multirow[b]{2}{*}{$\begin{array}{l}\text { Ruis- } \\
\text { lajike } \\
\text { Roggen- } \\
\text { sorte }\end{array}$} & \multicolumn{5}{|c|}{ Torajyviä - Mutterkörner } \\
\hline & & $\mathrm{kg} / \mathrm{ha}$ & $\begin{array}{l}\text { Suhdeluku } \\
\text { Verhältnis- } \\
\text { zahl }\end{array}$ & $\begin{array}{l}\mathrm{kpl} / \mathrm{m}^{2} \\
\text { St. } / \mathrm{m}^{2}\end{array}$ & $\begin{array}{l}\text { Suhdeluku } \\
\text { Verhältnis- } \\
\qquad z a h l\end{array}$ & $\begin{array}{l}\text { keskim. } \\
\text { kpl/tähkä } \\
\text { im Mittel } \\
\text { St./Ähre }\end{array}$ \\
\hline $\mathrm{F}$ & Ensi & $313.6 \pm 45.2$ & 100 & $683 \pm 121$ & 100 & $1.2 \pm 0.12$ \\
\hline $\mathrm{D}_{2}$ & ) & $54.9 \pm 6.6$ & 18 & $160 \pm 24$ & 23 & $0.5 \pm 0.16$ \\
\hline & $\mathrm{m}_{d}$ & $258.7 \pm 45.7 *$ & & $523 \pm 12$ & & $0.7 \pm 0.20 *$ \\
\hline
\end{tabular}

Taulukko 7. Eri torajyväkantojen sadot Ensirukiissa vuosina $1954-1955$ (v. $1954: 3 \times 5 \mathrm{~m}^{2} ; \mathrm{v}$. 1955 : $\left.3 \times 3 \mathrm{~m}^{2}\right)$.

Tabelle 7. Die Erträge der verschiedenen Mutterkornstämme am Roggen Ensi in den J. 1954-1955 (1954: $\left.3 \times 5 \mathrm{~m}^{2} ; 195.5: 3 \times 3 \mathrm{~m}^{2}\right)$.

\begin{tabular}{|c|c|c|c|c|c|c|c|c|}
\hline \multirow{3}{*}{$\begin{array}{c}\text { Torajyvä- } \\
\text { kanta } \\
\text { Mutter- } \\
\text { korn- } \\
\text { stamm }\end{array}$} & \multicolumn{8}{|c|}{ Torajyviä - Mutterkörner } \\
\hline & \multicolumn{5}{|c|}{1954} & \multicolumn{2}{|c|}{1955} & \\
\hline & $\mathrm{kg} / \mathrm{ha}$ & $\begin{array}{l}\text { Suhdeluku } \\
\text { Verhältnis- } \\
\text { zahl }\end{array}$ & $\begin{array}{l}\mathrm{kpl} / \mathrm{m}^{2} \\
\mathrm{St} . / \mathrm{m}^{2}\end{array}$ & $\begin{array}{l}\text { Suhdeluku } \\
\text { Verhältnis- } \\
\text { zahl }\end{array}$ & $\mathrm{kg} / \mathrm{ha}$ & $\begin{array}{l}\text { Suhdeluku } \\
\text { Verhältnis- } \\
z a h^{\prime}\end{array}$ & $\begin{array}{l}\mathrm{kpl} / \mathrm{m}^{2} \\
\text { St. } / \mathrm{m}^{2}\end{array}$ & $\begin{array}{l}\text { Suhdeluku } \\
\text { Verhältnis- } \\
\text { zahl }\end{array}$ \\
\hline $\mathrm{F}$ & $402.3 \pm 13.6$ & 100 & $1305 \pm 49$ & 100 & $196.4 \pm 14.6$ & 100 & $352 \pm 25$ & 100 \\
\hline $\mathrm{D}_{1}$ & $210.8 \pm 17.9$ & 52 & $828 \pm 43$ & 63 & $294.6 \pm 13.8$ & 150 & $502 \pm 28$ & 143 \\
\hline $\mathrm{D}_{2}$ & $238.7 \pm 28.4$ & 59 & $584 \pm 56$ & 45 & - & - & - & - \\
\hline $\mathrm{P}_{2}$ & $208.4 \pm 45.6$ & 52 & $841 \pm 164$ & 64 & $224.9 \pm 22.2$ & 115 & $447 \pm 43$ & 127 \\
\hline $\mathrm{P}_{3}$ & $112.0 \pm 17.3$ & 28 & $396 \pm 37$ & 30 & $21.8 \div 0.7$ & 11 & $57 \pm 6$ & 16 \\
\hline
\end{tabular}




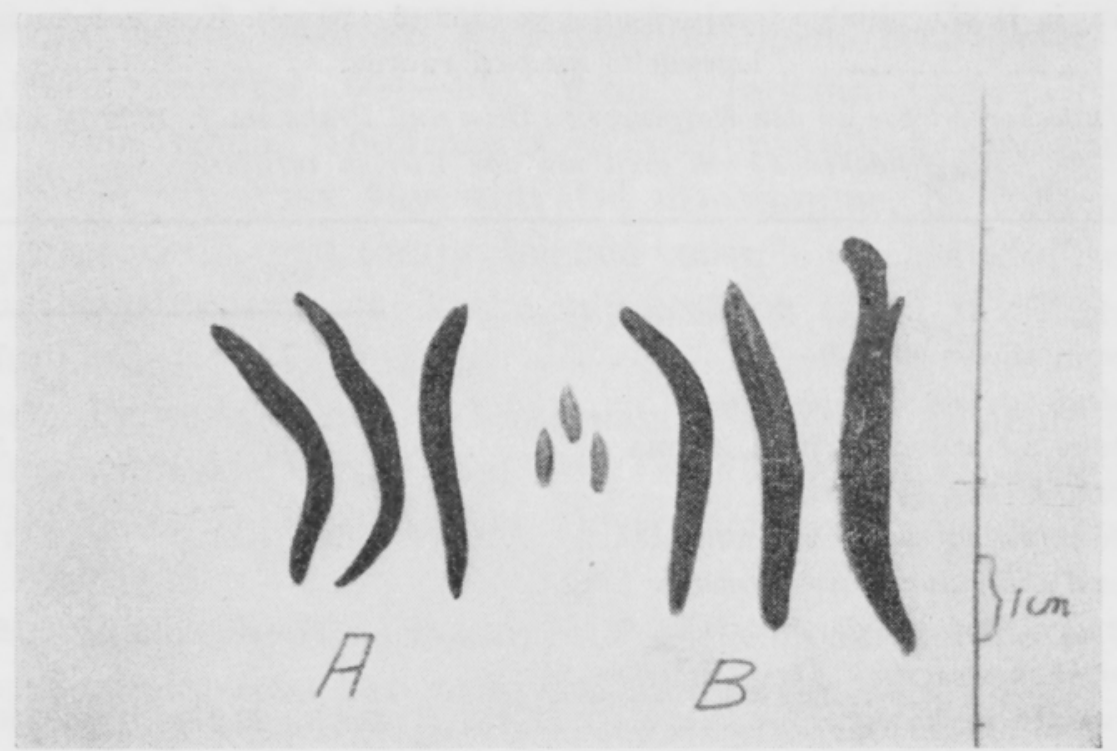

Kuva 4. F-sklerootioita (A), $\mathrm{D}_{1}$-sklerootioita (B) vuodelta 1952 verrattuna rukiin jyviin (keskellä). Abb. 4. F-Sklerotien (A), $D_{1}$-Sklerotien (B) vom Jahre $1952 \mathrm{im}$ Vergleich mit Roggenkörnern (Mitte).

myöskään onnistuttu eristämään. Toisaalta on kirjallisuudessa esiintynyt tietoja siitä, että sklerootioiden kehitys voi pysähtyä rihmastoasteeseen myös sienen heikon virulenssin takia $(20)$.

Eri torajyväkantojen sklerootioiden 1000 jyvän painojen välillä kaikki koevuodet huomioon ottaen ei todettu varmoja eroja. Suurimmat $\mathrm{D}_{1}$-sklerootiot olivat n. $500 \mathrm{mg}: \mathrm{n}$ painoisia ja $4-5 \mathrm{~cm}$ :n pituisia (kuva 4). Niiden, samoin kuin muidenkin ulkomaisten torajyväkantojen sklerootioiden väri oli ruskeanharmaa, kotimaisen, F:n, musta tai mustan ja harmaan kirjava. Sklerootion murtopinta oli F:ssä kiiltävän valkea, muissa torajyväkannoissa himmeä ja likaisen kellervä.

\section{Ruislaiikkeiden vertailu}

Torajyvän viljelyyn liittyy varsin kiinteästi myös saastutuksiin sopivien ruislajikkeiden valinta. Kirjallisuudessa on esiintynyt tietoja, että luonnonvarainen ruis, Secale montanum Guss. saastuu erittäin voimakkaasti (3), samoin kuin sen ja viljellyn rukiin bastardit (7), jotka ovat sterilisyyteen taipuvaisia. Sen sijaan viljellyn rukiin eri lajikkeiden torajyvätaudin alttiudessa ei ole todettu mainittavia eroja (12). Viime aikoina on kuitenkin suoritettu myös tetraploidirukiin saastutuksia $(6,19)$ ja todettu, että se saastuu voimakkaammin kuin diploidiruis.

Viikin koetilan kokeissa Oiva- ja Pekka-syysrukiit oli sijoitettu tavanomaiseen lajikekokeeseen, jossa lajikkeiden luku oli kaikkiaan 6. Saastutuksiin käytetty torajyväkanta oli saksalainen $D_{1}$. Pekkarukiin kasvusto oli keväällä vähän tiheämpi kuin Oivan (taulukko 8). Sen sijaan torajyväsadon korjuun aikana näiden lajikkeiden tähkäluvussa $\mathrm{m}^{2}$ ja ruisyksilöä kohden suhde oli päinvastainen. Koska myös eri koeruutujen saastutus oli suoritettu niin samanaikaisesti kuin oli mahdollista (vrt. taulukko 8), lienee Pekan torajyväsadon, $523 \mathrm{~kg} /$ ha, eroa Oivan torajyvä- 
Taulukko 8. Oiva- ja Pekkarukiiden torajyväsadot v. $1952\left(6 \times 20 \mathrm{~m}^{2}\right)$. Koeruudut saastutettu $45 \mathrm{~cm}: \mathrm{n}$ leveydeltä ympäri ruutua.

Tabelle 8. Die Mutterkornerträge an den Roggensorten Oiva und Pekka im J. $1952\left(6 \times 20 \mathrm{~m}^{2}\right)$. Die Probeflächen $4.5 \mathrm{~cm}$ breit um das Viereck infiziert.

\begin{tabular}{|c|c|c|}
\hline & Oiva & Pekka \\
\hline $\begin{array}{l}\text { Kasvuston tiheys } 8.5 .(0-10) \quad \ldots \cdots \cdots \cdots \cdots \cdots \\
\text { Bestandesdichte am } 8.5 .(0-10)\end{array}$ & 7.1 & 7.9 \\
\hline $\begin{array}{l}\text { Tähkäluku } / \mathrm{m}^{2} \text { sadon korjuun aikana .......... } \\
\text { Ährenzahl } / \mathrm{m}^{2} \text { zur Erntezeit }\end{array}$ & 563 & 541 \\
\hline $\begin{array}{l}\text { Tähkäluku/yksilö sadon korjuun aikana } \ldots . . . \\
\text { Ährenzahl/Individuum zur Erntezeit }\end{array}$ & $2.99 \pm 1.11$ & $2.81 \pm 0.10$ \\
\hline $\begin{array}{l}\text { Saastutuspäivänä tähkiä näkyvissä } \% \quad \ldots \ldots \ldots \\
\text { Am Infektionstage sind Ähren zu sehen } \%\end{array}$ & $25-85$ & $10-65$ \\
\hline $\begin{array}{l}\text { Torajyväsato } \mathrm{kg} / \mathrm{ha} \ldots \ldots \ldots \ldots \ldots \ldots \ldots \ldots \ldots \\
\text { Mutterkornertrag } \mathrm{kg} / \mathrm{ha}\end{array}$ & $\left.358.5 \pm 23.9^{1}\right)$ & $\left.522.8 \pm 37.0^{1}\right)$ \\
\hline $\begin{array}{l}\text { Torajyväsato, suhdeluku } \ldots \ldots \ldots \ldots \ldots \ldots \ldots \\
\text { Mutterkornertrag, Verhältniszahl }\end{array}$ & 100 & 145 \\
\hline $\begin{array}{l}\text { Torajyväsato } \mathrm{kpl} / \mathrm{m}^{2} \quad \ldots \ldots \ldots \ldots \ldots \ldots \ldots \ldots \\
\text { Mutterkornertrag St. } / \mathrm{m}^{2}\end{array}$ & $\left.816 \pm 53^{2}\right)$ & $\left.846 \pm 68^{2}\right)$ \\
\hline $\begin{array}{l}\text { Torajyväsato, suhdeluku } \ldots \ldots \ldots \ldots \ldots \ldots \ldots \\
\text { Mutterkornertrag, Verhältniszahl }\end{array}$ & 100 & 104 \\
\hline
\end{tabular}

satoon, $359 \mathrm{~kg} / \mathrm{ha}$, pidettävä ruislajikkeiden erilaisuudesta johtuvana, varsinkin kun satoero ratkaisevasti johtui siitä, että Pekkarukiin tähkissä kasvaneet sklerootiot olivat kooltaan suurempia.

Kevätruista ei Suomessa nykyään yleensä viljellä, mutta koska sekin kirjallisuustietojen mukaan hyvin soveltuu torajyväsaastutuksiin $(12,25)$, suoritettiin Viikin koetilalla myös saksalaisen Petkus-kevätrukiin saastutuksia; kokeessa käytettiin $10 \mathrm{~m}^{2}$ :n koeruutuja ilman kerrannaisia. Tulokset saastutuksista olivat:

Torajyväkanta

Rukiin kasvuston tiheys 12.6. $(0-10)$

Tähkäluku/ $\mathrm{m}^{2}$ sadon korjuun aikana

Tähkäluku/yksilö

Saastutuspäivänä tähkiä näkyvissä \%

Torajyväsato $\mathrm{kg} / \mathrm{ha}$

$\mathrm{kpl} / \mathrm{m}^{2}$
F

(koealue 1)

10

443

1.55

95

604.4

2515
$\mathrm{D}_{1}$ (koealue 2)

10

409

1.36

85

852.4

1861

Petkus-kevätrukiin kasvusto oli jokseenkin aukotonta ja myös tähkiminen erittäin tasaista, mikä ilmenee mm. pienestä tähkäluvusta ruisyksilöä kohden. Tämä suuresti helpottikin saastutustyön suorittamista. Myös sateinen sää kevätrukiin

1) Erotuksen 164.3 keskivirhe $\pm 44^{* *}$

Mittlerer Fehler des Unterschiedes $164.3= \pm 44^{* *}$

2) Erotuksen 30 keskivirhe \pm 86

Mittlerer Fehler des Unterschiedes $30= \pm 86$ 
kukinnan aikana lienee osaltaan vaikuttanut siihen, että saatu torajyväsato muodostui erittäin suureksi, $604-852 \mathrm{~kg} / \mathrm{ha}$. Joskaan yksivuotisten kokeiden perusteella ei vielä voida tehdä varmoja johtopäätöksiä kevätrukiin soveltuvuudesta torajyvän viljelyssä käytettäväksi maassamme, on kuitenkin ilmeistä, että kosteussuhteet meillä ovat torajyväsienen kasvulle yleensä edullisemmat kevätkuin syysrukiin saastumisaikana, koska syyskesä on täällä tavallisesti alkukesää runsassateisempi.

Saksalaisen Petkus-syysrukiin torajyväsato muodostui siemenen puutteellisen jarovisoitumisen takia varsin pieneksi $(12-27 \mathrm{~kg} / \mathrm{ha})$. Saastutusajankohdan (2.8.) myöhäisyydestä johtuen kaikki sklerootiot eivät myöskään ennättäneet tuleentua.

Ohran saastutuskoe osoitti selvästi, että se ei kelpaa isäntäkasviksi tutkittuja torajyväkantoja viljeltäessä. Sen torajyväsadot olivat vain $13-20 \mathrm{~kg} / \mathrm{ha}$.

\section{Torajyvien alkaloidipitoisuus}

Torajyvien sisältämät alkaloidit jaetaan vesiliukoisiin ja veteenliukenemattomiin; edellisiin kuuluu ergometriini (ergobasiini), jälkimmäisiä ovat ergotoksiini- ja ergotamiinialkaloidiryhmät, joista viimeksi mainittua pidetään kaikkein arvokkaimpana $(1,4,9,10,11,17,21,22,24,25,26,28,31)$.

Viikin koetilan kokeissa viljeltyjen torajyvien alkaloidien määrittäminen suoritettiin osaksi Saksassa, Gaterslebenissä, osaksi Helsingin yliopiston farmakologisessa

Taulukko 9. Saksalaisen $D_{1}$-torajyväkannan alkaloidipitoisuus v. 1952 (25).

Tabelle 9. Der Alkaloidgehalt des deutschen Mutterkornstammes $D_{1}$ im J. 1952 (25).

\begin{tabular}{|c|c|c|c|c|}
\hline \multirow{3}{*}{$\begin{array}{c}\text { Koepaikka ja ruislajike } \\
\text { Versuchsstelle und } \\
\text { Roggensorte }\end{array}$} & \multicolumn{4}{|c|}{$\begin{array}{l}\text { Alkaloideja \% } \\
\text { Alkaloide \% }\end{array}$} \\
\hline & \multirow{2}{*}{$\begin{array}{l}\text { Vesiliukoisia } \\
\text { Wasserlöslich } \\
\text { Laskettu } \\
\text { ergometriini- } \\
\text { nä - Berech- } \\
\text { net als Ergo- } \\
\text { metrin }\end{array}$} & \multicolumn{2}{|c|}{$\begin{array}{l}\text { Veteenliukenemattomia } \\
\text { Wasserunlöslich }\end{array}$} & $\begin{array}{c}\text { Yhteensä } \\
\text { Zus. }\end{array}$ \\
\hline & & \multicolumn{3}{|c|}{$\begin{array}{l}\text { Laskettu ergotamiinina } \\
\text { Berechnet als Ergotamin }\end{array}$} \\
\hline \multicolumn{5}{|l|}{ Viik } \\
\hline 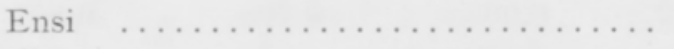 & 0.025 & 0.045 & 0.214 & 0.259 \\
\hline Oiva $\quad \ldots \ldots \ldots \ldots \ldots \ldots \ldots \ldots \ldots \ldots$ & 0.026 & 0.046 & 0.195 & 0.241 \\
\hline Pekka ........................ & 0.030 & 0.053 & 0.191 & 0.244 \\
\hline $\begin{array}{l}\text { Petkus, kevätruis } \ldots \ldots \ldots \ldots \ldots \ldots \ldots \\
\text { Sommerroggen }\end{array}$ & 0.021 & 0.038 & 0.188 & 0.226 \\
\hline $\begin{aligned} \text { Petkus, } & \text { syysruis } \ldots \ldots \ldots \ldots \ldots \ldots \ldots \ldots \\
& \text { Winterroggen }\end{aligned}$ & 0.012 & 0.022 & 0.133 & 0.155 \\
\hline \multicolumn{5}{|l|}{ Gatersleben } \\
\hline $\begin{array}{l}\text { Syysruis } \ldots \ldots \ldots \ldots \ldots \ldots \ldots \ldots \ldots \ldots \\
\text { Winterroggen }\end{array}$ & 0.047 & 0.084 & 0.192 & 0.276 \\
\hline
\end{tabular}


laitoksessa. Alkaloidien määrittämisessä käytettyjä menetelmiä ovat asianomaiset tutkijat selostaneet julkaisuissaan $(11,26)$.

Analysointeja on suoritettu Viikissä viljeltyjen $\mathrm{D}_{1^{-}}, \mathrm{D}_{4^{-}}$ja $\mathrm{F}$ - sekä eri kasvinviljelyskoeasemilla kokeissa mukana olleiden $\mathrm{D}_{2^{-}}, \mathrm{D}_{3^{-}}, \mathrm{P}_{1^{-}}, \mathrm{P}_{2^{-}}$ja $\mathrm{P}_{3}$ torajyväkantojen sklerootioista.

Saksassa (25) suoritettujen analysointien tuloksista ilmenee, että saksalaisen $\mathrm{D}_{1}$-torajyväkannan kokonaisalkaloidipitoisuus muodostui Viikin kenttäkokeissa v. 1952 keskimäärin lähes samaksi kuin Gaterslebenissä; prosenttiluvut vaihtelivat $0.155-0.259$ (taulukko 9).

Yhdenmukaisesti aikaisempien tutkimusten (4) kanssa todettiin, että ruislajikkeella ei ollut huomattavaa erikoisvaikutusta torajyvien alkaloidipitoisuuteen (taulukko 9). Tosin jarovisoidun Petkus-syysrukiin tähkissä kasvaneiden sklerootioiden alkaloidipitoisuus oli suhteellisen pieni, $0.155 \%$, mutta otettaessa huomioon tämän lajikkeen poikkeuksellisen myöhäinen saastutusaika (2.8.), on otaksuttavissa, että alhainen alkaloidipitoisuus johtui torajyvän kasvuaikana vallinneista olosuhteista, lähinnä siten, että torajyvä ei ennättänyt täysin tuleentua. Saastutuskokein todettiin niinikään, että tämä alkaloidipitoisuusero ei johtunut torajyväkannan mutaatiosta (vrt. 25).

Pohjoisilla koeasemilla sekä portugalilaisten torajyväkantojen että saksalaisen $\mathrm{D}_{3}$-kannan alkaloidipitoisuus (taulukko 10) muodostui (v. 1953) sangen korkeaksi;

Taulukko 10. V. 1953 viljeltyjen torajyväkantojen alkaloidipitoisuus (25).

Tabelle 10. Der Alkaloidgehalt (25) der im J. 1953 gezüchteten Mutterkornstämme.

\begin{tabular}{|c|c|c|c|c|c|c|}
\hline \multirow{3}{*}{$\begin{array}{l}\text { Koepaikka } \\
\text { Versuchsort }\end{array}$} & \multirow{3}{*}{\multicolumn{2}{|c|}{$\begin{array}{c}\text { Torajyvä- } \\
\text { kanta } \\
\text { Mutterkorn- } \\
\text { stamm }\end{array}$}} & \multicolumn{4}{|c|}{$\begin{array}{l}\text { Alkaloideja \% } \\
\text { Alkaloide } \%\end{array}$} \\
\hline & & & \multirow{2}{*}{$\begin{array}{l}\text { Vesiliukoisia } \\
\text { Wasserlöslich } \\
\text { Laskettu } \\
\text { ergometriini- } \\
\text { nä - Be- } \\
\text { rechnet als } \\
\text { Ergometrin }\end{array}$} & \multicolumn{2}{|c|}{$\begin{array}{c}\text { Veteenliukenemattomia } \\
\text { Wasserunlöslich }\end{array}$} & $\begin{array}{l}\text { Yhteensä } \\
\text { Zus. }\end{array}$ \\
\hline & & & & \multicolumn{3}{|c|}{$\begin{array}{l}\text { Laskettu ergotamiinina } \\
\text { Berechnet als Ergotamin }\end{array}$} \\
\hline Maaninka & $\mathrm{D}_{3}$ & $\ldots \ldots \ldots \ldots \ldots \ldots$ & 0.041 & 0.073 & 0.282 & 0.355 \\
\hline$"$ & $"$ & $\ldots \ldots \ldots \ldots \ldots \ldots$ & 0.041 & 0.073 & 0.284 & 0.357 \\
\hline Gatersleben & 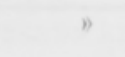 & $\ldots \ldots \ldots \ldots \ldots \ldots \ldots$ & 0.060 & 0.108 & 0.236 & 0.344 \\
\hline Ruukki & $\mathrm{P}_{1}$ & $\ldots \ldots \ldots \ldots \ldots \ldots \ldots$ & 0.052 & 0.093 & 0.708 & 0.801 \\
\hline Gatersleben & $n$ & $\ldots \ldots \ldots \ldots \ldots \ldots$ & 0.089 & 0.160 & 0.609 & 0.769 \\
\hline Ruukki & $\mathrm{P}_{2}$ & $\ldots \ldots \ldots \ldots \ldots \ldots$ & 0.028 & 0.050 & 0.458 & 0.508 \\
\hline$"$ & $"$ & $\ldots \ldots \ldots \ldots \ldots \ldots$ & 0.027 & 0.048 & 0.456 & 0.504 \\
\hline Gatersleben & $n$ & $\ldots \ldots \ldots \ldots \ldots \ldots$ & 0.049 & 0.088 & 0.352 & 0.440 \\
\hline 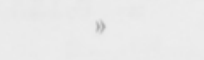 & " & $\ldots \ldots \ldots \ldots \ldots \ldots$ & 0.074 & 0.132 & 0.302 & 0.434 \\
\hline Apukka & $\mathrm{P}_{3}$ & $\ldots \ldots \ldots \ldots \ldots \ldots$ & 0.031 & 0.055 & 0.621 & 0.676 \\
\hline$"$ & $n$ & $\ldots \ldots \ldots \ldots \ldots \ldots \ldots$ & 0.031 & 0.055 & 0.619 & 0.674 \\
\hline Gatersleben & $n$ & $\ldots \ldots \ldots \ldots \ldots \ldots$ & 0.055 & 0.100 & 0.411 & 0.511 \\
\hline
\end{tabular}


osittain tämä tosin johtuu alkaloidien määritystavassa tapahtuneesta muutoksesta (vrt. 25). Samalla on kuitenkin todettavissa, että torajyvän kokonaisalkaloidipitoisuus on Apukassa (n. $67^{\circ}$ pohj. lev.) muodostunut vähintään yhtä korkeaksi kuin Saksassa. Maaningalla viljellyn, $\mathrm{D}_{2}$-torajyväkannan sklerootiot eivät olleet normaalisti-kehittyneitä; niiden alkaloidipitoisuus oli SILBERin ystävällisesti lähettämän tiedon mukaan vain $0.212 \%$.

Myös vehnästä eristetyn, $\mathrm{D}_{4}$-torajyväkannan kokonaisalkaloidipitoisuus muodostui Viikin koetilalla $(0.249 \%)$ lähes samaksi kuin Saksassa $(0.234 \%$; 25$)$, joten on pääteltävissä, että torajyvien alkaloidipitoisuus on lähinnä geneettisistä tekijöistä johtuva. Kuitenkin vesiliukoisten alkaloidien osuus kokonaisalkaloidipitoisuuksista oli jonkin verran pienempi Suomessa kuin Saksassa viljellyssä torajyvässä (taulukot $9-10)$.

Farmakologisessa laitoksessa Helsingissä suoritettujen kvantitatiivisten analyysien tulokset olivat edellä esitettyjen kanssa samansuuntaisia (taulukko 11). Torajyvien korjuuaikaa siirrettäessä myöhäisemmäksi niiden alkaloidipitoisuus kasvoi, ilmeisesti johtuen siitä, että silloin yhä useammat sklerootiot ennättivät


analyysitulosten mukaan.

Tabelle 11. Der Alkaloidgehalt der Mutterkornstämme $D_{1}$ und $F$ in den Jahren 1952 - 1953 nach den von JÄRVINEN eingesandten Analysenergebnissen.

\begin{tabular}{|c|c|c|c|c|}
\hline \multirow{4}{*}{$\begin{array}{l}\text { Torajyvä- } \\
\text { kanta } \\
\text { Mutterkorn- } \\
\text { stamm }\end{array}$} & \multirow{4}{*}{$\begin{array}{l}\text { Ruislajike } \\
\text { Roggensorte }\end{array}$} & \multicolumn{3}{|c|}{$\begin{array}{l}\text { Alkaloideja } \% \\
\text { Alkaloide } \%\end{array}$} \\
\hline & & \multirow{3}{*}{\multicolumn{2}{|c|}{$\begin{array}{rc} & \text { Veteen liuke- } \\
\text { Vesiliukoisia nemattomia } & \text { nasserlöslich } \\
\text { Waser- } \\
& \text { unlöslich }\end{array}$}} & \\
\hline & & & & Yhteensä \\
\hline & & & & Zus. \\
\hline
\end{tabular}

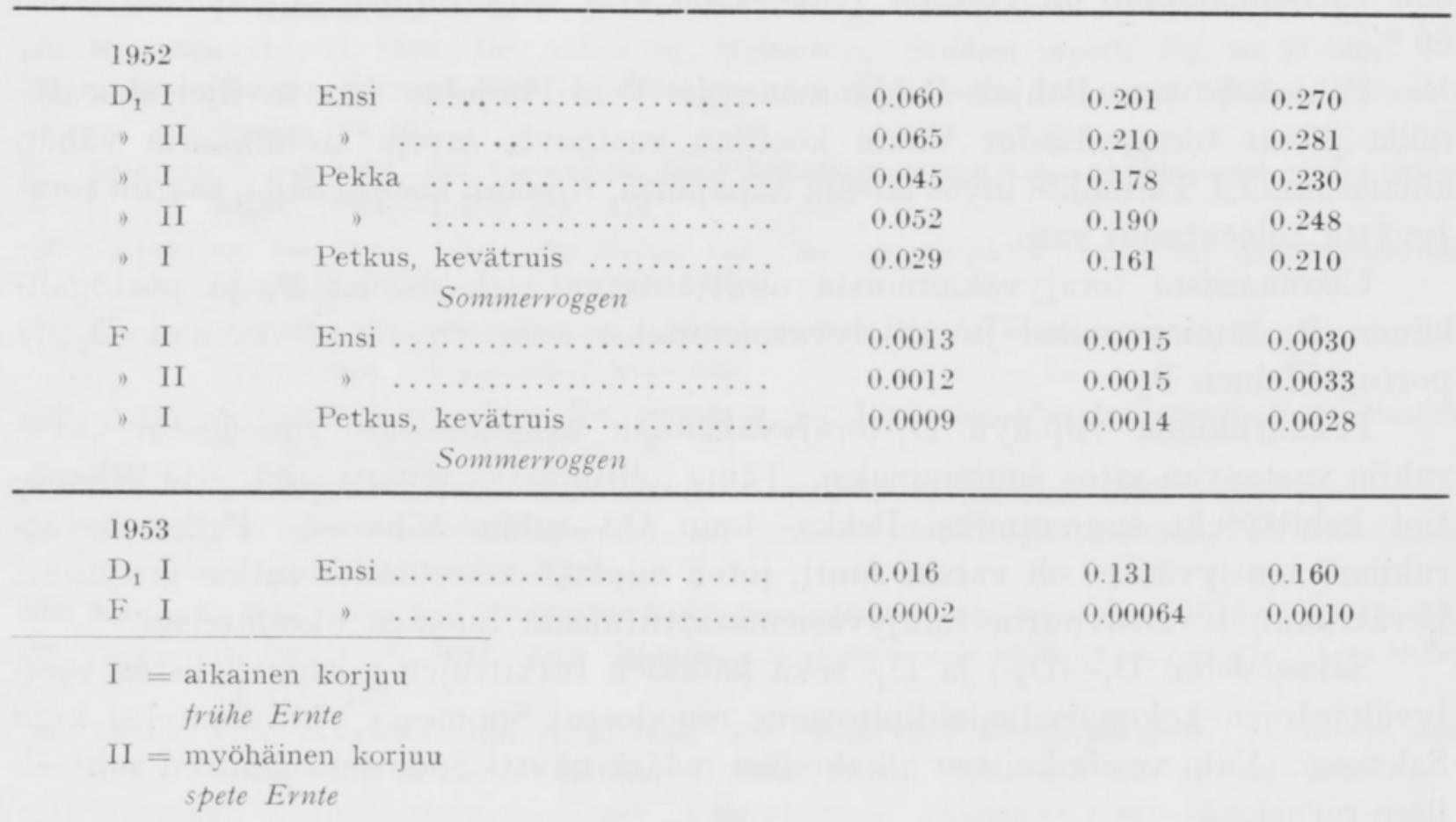


tuleentua (vrt. 22, 25). Torajyvien herkän varisemisen takia niiden korjuuaikaa ei kuitenkaan voida siirtää kovin myöhäiseksi (kuva 3).

Vasta jatketuilla tutkimuksilla voitaneen selvittää, kuinka pysyväksi ulkomailta tuotettujen torajyväkantojen alkaloidipitoisuus maassamme muodostuu. Kotimaisen torajyväkannan nykyinen heikko alkaloidipitoisuus ja toisaalta viime vuosisadalla sattuneet torajyvän aiheuttamat joukkomyrkytykset (27) viittaavat siihen, että täällä on aikaisemmin esiintynyt torajyväkantaa, jonka alkaloidipitoisuus on ollut nykyistä suurempi. Varmuudella ei ole pääteltävissä, onko sen alkaloidipitoisuus aikojen kuluessa muuttunut, vai onko se olosuhteisiimme sopeutumattomana karsiutunut Suomen torajyväsienikasvistosta.

\section{$P \ddot{a} \ddot{a}$ tel $m$ i ̈̈}

Tutkituista kasvualustoista soveltui Claviceps purpurea (Fr.) Tul.:n kuromien kasvattamiseen KIRCHнoffin (12) suosittelema ravintoagari kaikkein parhaiten. Myös erilaiset viljanjyväalustat olivat käyttökelpoisia.

Saastutusaikakokeen tulokset osoittivat, että sopivin saastutusaika on silloin kun $35-85 \%$ rukiin tähkistä on vapautunut lehtitupesta; eräässä koesarjassa saatiin runsas torajyväsato, kun $10-85 \%$ tähkistä oli näkyvissä. Torajyväsienen kehityksen kulkuun, sen Sphacelia-asteen ja sklerootioiden muodostumisen alkamiseen, ei saastutuksen ajankohdalla näyttänyt olleen vaikutusta, edellytettynä, että saastutus tapahtui ajalla 9. 6.-2. 8 .

Viikin koetilan kokeissa vuosina 1952-1955 saadut rukiin torajyväsadot (tähkistä poimitut) olivat $83-258 \mathrm{~kg} / \mathrm{ha}$; v. 1952, jolloin saastutusajan sää oli kostea, sadon määrä muodostui suurimmaksi.

Torajyvän maahan varisemista tapahtui huomattavassa määrin vaikka, suurin osa sklerootioista korjattiin n. viikkoa ennen rukiin tuleentumista. Keskimääräinen varisemistappio oli vuosina 1952-1955 41.4\%, äärimmäistapauksessa lähes $80 \%$.

Pohjois-Savon, Pohjois-Pohjanmaan ja Perä-Pohjolan kasvinviljelyskoeasemilla jäivät torajyväsadot Viikin koetilan vastaavia satoja keskimäärin vähän alhaisemmiksi, kuitenkin myös lähellä napapiiriä, Apukan koeasemalla, saatiin torajyvästä tuleentunut sato.

Ulkomaisista torajyväkannoista osoittautuivat saksalainen $D_{1}$ ja portugalilainen $\mathrm{P}_{2}$ satoisammiksi ja viljelyvarmemmiksi kuin $\mathrm{D}_{1}$ :stä polveutuva $\mathrm{D}_{2}$ ja portugalilainen $\mathrm{P}_{3}$.

Pekkarukiissa viljellyn $\mathrm{D}_{1}$-torajyväkannan sklerootiosato muodostui Oivarukiin vastaavaa satoa suuremmaksi. Tämä johtui ratkaisevasti siitä, että sklerootiot kehittyivät suuremmiksi Pekka- kuin Oivarukiin tähkissä. Petkus-kevätrukiissa torajyväsato oli varsin suuri, joten näyttää aiheelliselta tutkia erityisesti kevätrukiin soveltuvuutta torajyväsienisaastutuksiin Suomen olosuhteissa.

Saksalaisten $\mathrm{D}_{1^{-}}\left(\mathrm{D}_{3}^{-}\right)$ja $\mathrm{D}_{4^{-}}$sekä kaikkien tutkittujen portugalialisten torajyväkantojen kokonaisalkaloidipitoisuus muodostui Suomessa yhtä suureksi kuin Saksassa. Vain vesiliukoisten alkaloidien määrä näytti Suomessa jääneen suhteellisen pieneksi. 


\section{KIR JALLISUUTTA}

(1) Aно, E. 1953. Torajyvän viljelemisestä Suomessa. Farm. aikak. 5: 115-129.

(2) Barger, G. 1931. Ergot and ergotism. 279 s. London-Edinburgh.

(3) BÉKÉSY, N. von 1938-1939. Über parasitische Mutterkornkulturversuche. Zbl. Bakt. Parasitenkunde $99: 321-332$.

(4) - 1940. Untersuchungen über den Alkaloidgehalt des Mutterkornes. II Mitteilung: Über den Alkaloidgehalt des parasitisch kultivierten Nutterkornes. B:ochem Z. 103: 368-382.

(5) Bonnier, G. ja Tedin, O. 1940. Biologisk variationsanalys. $325 \mathrm{~s}$. Stockholm.

(6) Deufel, J. 1952. Die Züchtung von Mutterkorn (Claviceps purpurea) auf tetraploidem Roggen. Naturwiss. 39: 432-433.

(7) Hecke, L. 1921. Die Kultur des Mutterkerns. Schw. Apoth. Ztg. 59: 277-281, $293-296$.

(8) —- 1922. Die Kultur des Mutterkorns. Ibid. 60, 4:45-51.

(9) JARETZKY, R. 1935. Alkaloidgehalt und Wirksamkeit saprophytischer Mutterkornkulturen. Arch. Pharm. Berl. 273: 348-357.

(10) Joutsiala, A. 1945. Torajyväalkaloidien määrittämismenetelmistä ja suomalaisen torajyvän alkaloidipitoisuudesta. Semina 29: 132-137, 188-196.

(11) Järvinen, P. A. 1953. Uber die pharmakodynamischen und klinischen Wirkungen des finnischen Mutterkorns. 82 s. Helsinki.

(12) Kirchhoff, H. 1929. Beiträge zur Biologie und Pfysiologie des Mutterkornpilzes. Cbl. Bakt. Parasitenkunde 77:310-369.

(13) Krebs, J. 1936. Untersuchungen über den Pilz des Mutterkorns Claviceps purpurea Tul. Ber. Schw. bot. Ges. 45: $71-165$.

(14) Kreitmair, H. ja Küssner, W. 1931. Über den Alkaloidgehalt von Claviceps purpurea bei Kultivierung auf künstlichen Nährböden. Biochem. Z, 239: 189-192.

(15) Kuukausikatsaus Suomen sääoloihin. Ilmat. keskusl. vuosik. 46-49.

(16) Langdon, R. F. 1942. The genus Cerebella Cesati - its biologic status and use. Phytop. $32: 613-617$.

(17) Loo, Y. H. ja Lewis, R. W. 1955. Alkaloid formation in ergot sclerotia. Sci. 121: $367-368$.

(18) Mc CreA, A. 1931. The reactions of Claviceps purpurea to variations of environment. Amer. J. Bot. 18: $50-77$.

(19) Mothes, K. ja Silber, A. 1952. Über den natürlichen Befall der Roggenfelder durch Mutterkorn. Pharmazie 7: $310-313$.

(20) Rochelmeyer, H. 1950. Der Anbau von Mutterkorn. Süddeut. Apoth. Ztg. 90: 39 -43.

(21) Saha ja Bhattacharjee 1945. Artificial production of ergot in the tropical plains of Bengal. Nature 156: 363 .

(22) Schulze, T. von 1953. Zur Variabilität des Alkaloidgehalts von "Claviceps purpurea" in der Oberlausitz. Pharmazie 8: 412-416.

(23) Schweizer, Gg. 1941. Über die Kultur von Claviceps purpurea (Tul.) auf kaltsterilisierten Nährböden. Phytop. Z. 13: $317-350$.

(24) Silber, A. 1952. Der Alkaloidgehalt natürlich in Deutschland vorkommenden Mutterkorns des Jahres 1951. Pharmazie 7: 854-859.

(25) —- ja Bischoff, W. 1954. Die Konstanz des Alkaloidgehaltes bei verschiedenen Rassen von Mutterkorn. Ibid. 9: $46-61$.

(26) —- ja Schulze, T. 1953. Alkaloidbestimmungen im Mutterkorn. Ibid. 8: 675-679.

(27) Spoof, A. R. 1872. Om förgiftningar med secale cornutum, förnämligast med hensyn till Dragsjukan i Finland. 67 s. Helsingfors.

(28) Stoll, A. 1943. Altes und Neues über Mutterkorn. Mitt. Naturf. Ges. Bern 1942. 1943: 45-80.

(29) - - ja BRAck, A. 1944. Zum feldmässigen Anbau von Mutterkorn. Pharm. Act. Helv. 19: $118-123$.

(30) Tyler, V. E. ja Schwarting, A. E. 1952. The culture of Claviceps purpurea. I. Growth and nutrition in submerged culture. J. Amer. Pharm. Assoc. Sci. Ed. 11: 590-594.

(31) Wiechert, E. 1952. Mutterkornanbau in Mecklenburg. Pharmazie 7: 859 -862. 
R E F E R T :

\title{
ÜBER ANBAUVERSUCHE VON MUTTERKORN AUF DEM VERSUCHSGUT VIIK UND AN EINIGEN VERSUCHSSTATIONEN FÜR PFLANZENBAU IN FINNLAND.
}

\author{
AnNa-LiISA RUOKOLA
}

\section{Pflanzenpathologisches Institut der Universität Helsinki}

Konidien von Claviceps purpurea (Fr.) Tul. wurden für Infektionen von Roggen auf dem von KIRchноғF (12) empfohlenen Nähragar erzogen; auch verschiedene Getreidekornsubstrate erwiesen sich als brauchbar.

Die Ergebnisse des Infektionszeitversuchs erwiesen, dass die am besten geeignete Infektionszeit dann ist, wenn 35-85\% der Roggenähren sich von der Blattscheide befreit haben (Abb. 2); bei einer Versuchsreihe ergab sich ein reichlicher Mutterkornertrag, als $10-85 \%$ der Ähren zu sehen waren. Der Entwicklungsgang des Mutterkornpilzes, der Beginn der Bildung des Sphacelia-Stadiums und der Sklerotien scheint durch den Zeitpunkt der Infektion nicht beeinflusst worden zu sein, wenn die Infektion in der Zeit zwischen dem 9.6. und 2.8. vor sich ging (Tab. 2 und 3).

Die (von den Ähren gepflückten) Mutterkornerträge von Roggen, die sich in den Jahren 1952 1955 in den Versuchen auf dem Versuchsgut Wiik ergeben haben, betrugen $83-258 \mathrm{~kg} / \mathrm{ha}$ (Tab. 4); im J. 1952, als die Witterung der Infektionszeit feucht war, fiel die Ertragsmenge am grössten aus.

Das Abfallen des Mutterkornes geschah in beträchtlicher Menge, auch dann, wenn die Sklerotien schon eine Woche vor dem Reifen des Roggens geerntet wurden. Der durchschnittliche Verlust durch Abfallen belief sich in den Jahren 1952-1955 auf 41.4\% (Tab. 4), im Extremfalle auf annähernd $80 \%$. In dem trockensten Sommer 1955 (Tab. 1) war der Verlust durch Abfall am allergeringsten (10.3\%).

An den Versuchsstationen für Pflanzenbau in Nord-Savo $\left(63^{\circ} 9^{\prime}\right)$, Nord-Ostbottnien $\left(64^{\circ} 40^{\prime}\right)$ und im nördlichsten Nordfinnland $\left(66^{\circ} 35^{\prime}\right)$ blieben die Mutterkornerträge etwas niedriger als die entsprechenden Erträge auf dem Versuchsgut Viik $\left(60^{\circ}\right.$ 14 $\left.^{\prime}\right)$ (Tab. 5), doch auch nahe dem Polarkreis, an der Versuchsstation Apukka, erhielt man einen ausgereiften Ertrag an Mutterkorn.

Von den ausländischen Mutterkornstämmen erwiesen sich ein von Professor K. Mothes freundlich übersandter deutscher $\left(\mathrm{D}_{1}\right)$ und ein portugiesischer $\left(\mathrm{P}_{2}\right)$ als ertragreicher und anbausicherer als der aus $\mathrm{D}_{1}$ gezogene $\mathrm{D}_{2}$ und der portugiesische $\mathrm{P}_{3}$ (Tab. 6 und 7 ).

Der Sklerotienertrag des auf Pekka-Roggen gezogenen Mutterkornstammes $D_{1}$ fiel grösser aus als der entsprechende Ertrag auf Oiva-Roggen. Dies lag entschieden daran, dass sich die Sklerotien in den Ähren des Pekka-Roggens zu beträchtlicherer Grösse als in denen des Oiva-Roggens entwickelten (Tab. 8). Bei dem Sommerroggen Petkus war der Mutterkornertrag recht gross (600 -800 kg/ha), so dass es begründet erscheint, insbesondere die Eignung von Sommerroggen für Infektionen mit dem Mutterkornpilz zu untersuchen unter den in Finnland gegebenen Verhältnissen, wo der Spätsommer im allgemeinen feuchter als der Sommerbeginn ist.

Der Gesamtalkaloidgehalt der deutschen Mutterkornstämme $\mathrm{D}_{1}\left(\mathrm{D}_{3}\right)$ und $\mathrm{D}_{4}$ sowie aller untersuchten portugiesischen wurde in Finnland ebenso gross wie in Deutschland (Tab. 9-11). Nur die Menge der wasserlöslichen Alkaloide scheint in Finnland verhältnismässig gering geblieben zu sein. Bei Späterverlegung der Erntezeit der Mutterkörner nahm ihr Alkaloidgehalt zu (Tab. 11), zugleich aber stieg der Verlust durch Abfallen (Abb. 3). 